\title{
Catlocarpio siamensis.
}

Head large, flat above; eyes visible from below and not from above; mouth wide, terminal, maxillary extending to below anterior border of eye; lower lip much developed, but interrupted at the mandibular symphysis ; nostrils large ; eye $6 \frac{1}{2}$ times in length of head, 3 times in interorbital width; a much developed thin dermal fold bordering the gill-cover. Gill-rakers a little longer than gill-fringes, 110 on anterior arch. Depth of body equal to length of head, $2 \frac{2}{3}$ times in total length. Dorsal IV 9, originating above base of ventrals, at equal distance from the end of the snout and the base of the caudal; first branched ray longest, $\frac{3}{4}$ length of head. Pectoral a little shorter than ventral, a little more than $\frac{1}{2}$ length of head, reaching beyond base of ventral; latter fin reaching vent. Anal IV 5. Caudal deeply forked, middle rays not half as long as outer. Caudal peduncle as long as deep. Scales $39 \frac{6}{7^{\frac{1}{2}}} ; 5$ series of scales between lateral line and ventral; lateral line complete. Bronzy brown above, silvery beneath; fins blackish towards the end.

Total length 210 millim.

The British Museum has received from the Royal Siamese Museum, through its Curator, Mr. S. S. Flower, a single specimen of this highly interesting new fish. It was procured in the Menam River.

\section{LXX.-On Seven new Small Mammals from Ecuador and Venezuela. By Oldfield T'Homas.}

The British Museum owes to the generosity of Mr. Ludovic Söderström, Her Majesty's Consul at Quito, a small collection of mammals from Ecuador, and, besides several species obtained by Mr. L. Fraser and described by Mr. Tomes, there are examples of the two new species described below. Mr. Söderström was also the discoverer of the Ichthyomys Söderströmi and Pudua mephistopheles, described by Mr. de Winton in $1896 \%$. I have also taken the opportunity of describing some further new species recently received from Venezuela.

\section{Reithrodontomys Söderströmi, sp. n.}

Size fairly large, nearly equalling that of $R$. costaricensis, Allen. General colour dull greyish fawn, not nearly so rufous * P. Z. S. 1896, p. 507. 
as in $R$. costaricensis. Brighter lateral line little developed. Under surface not sharply defined, its colour much less bright than in costaricensis, the tips of the hairs more or less buffy or fawn-coloured. Ears thinly haired, brown, little darker than the general colour. Hands and feet white, without darker markings on the metapodials. Tail pale brown above and below, the tip white.

Skull low, with a flat superior profile. Palatal foramina short, barely reaching backward to the level of the front of $m .^{1}$.

Dimensions of the type (measured in skin) :-

Head and body 72 millim.; tail (extreme tip doubtfully perfect) 83 ; hind foot (wet) without claws 19 ; ear (wet) 14 .

Skull : back of parietal to nasal tip $21 \cdot 1$; greatest breadth 11.5 ; nasals $8.9 \times 2.6$; interorbital breadth 3.7 ; palate length from henselion $9 \cdot 2$; diastema $5 \cdot 9$; palatal foramina $4 \cdot 1 \times 1 \cdot 6$; length of upper molar series 3.8 .

Hab. Quito.

Type: B. M. no. 98. 5. 1. 9. Killed August 1897.

"Feeds on flowers and seeds in the gardens. Comes out from among the climbing plants every evening at about 7 Р.м." (L. Söderström).

This is by far the most southern record for the genus Reithrodontomys, which has not hitherto been found south of Costa Rica.

\section{APEOMYs *, gen. nov.}

Type Oryzomys (?) lugens, Thos. $\dagger$

Molars about as in Oryzomys. Skull in general shape, and especially in that of the anterior zygoma-root, as in the less specialized species of Oxymycterus. Thumb with a nail; claws not specially lengthened.

From what was said in the original description of " $O . l u$ gens" it will be understood with what doubt that species was placed in Oryzomys, and the discovery by Mr. Söderström of a second species closely allied to it renders it advisable that a genus should be formed for its reception.

\section{Equeomys vulcani, sp. n.}

Fur excessively long, soft, and woolly, the underfur about 12 and the longer hairs 15 millim. in length. General colour uniform dark buffy grey, not far from the "clove-brown" of Ridgway; this colour is slightly darker along the top of the

* ainos, a height.

† Ann. \& Mag. Nat. Hist. (6) xviii. p. 306 (1896). 
loins, but there is little difference over the rest of the upper surface. Projecting tips of longer hairs whitish. Belly not sharply defined, the hairs slate-coloured except at their extreme tips, which are buffy. Ears scarcely projecting from the long fur of the head, the anterior third of their outer surfaces black. Metapodials brown mesially, whitish laterally, as are also the digits. Tail shorter than in $\mathbb{E}$. lugens, barely as long as the head without the body, finely scaled, shorthaired, brown throughout.

The skull of the type is unfortunately very imperfect, but it differs from that of $A$. lugens by its shorter nasals and rather broader anterior zygoma-root. The slanting shape of the latter is quite as in the type species.

Dimensions of the type (measured in skin) :-

Head and body 111 millim.; tail 84; hind foot without claws 25 ; ear (approximately) 13.

Skull: length of nasals $10 \cdot 1$; interorbital breadth 6 ; diastema $7 \cdot 5$; palatal foramina $5 \cdot 5 \times 2 \cdot 1$. Lower jaw : condyle to incisor-tips $18 \cdot 1$; length of lower molar series $5 \cdot 7$.

$\mathrm{Hab}$. Mount Pichincha, Ecuador, at about 12,000 feet.

Type: B. M. no. 98. 5. 1. 10. Killed May 1897.

AE. vulcani may be distinguished from its ally $A$. lugens by its longer softer fur and much shorter tail.

\section{Thomasomys paramorum, sp. $\mathrm{n}$.}

Considerably smaller than $T$. cinereus. Fur long, soft, and woolly, the hairs on the back about 15 millim. in length. General colour, so far as can be made out in a spirit-specimen, dark rufous brown; belly dull whitish, not sharply defined. Ears large, evenly rounded, without anterior basal projection, well-haired, dark brown. Hands and feet white above, without darker metapodials. Tail long, well-haired, the hairs almost hiding the scales, but not specially pencilled at its tip; brown above, rather lighter below, but not markedly bicolor. Mammæ $1-2=6$.

Skull slender and very delicately built, the bones of the brain-case exceedingly thin and papery. Muzzle narrow. Interorbital region parallel-sided, narrow, its edges rounded, without ridges, though it is flattened mesially. Brain-case long, narrow, smoothly rounded. Front edge of zygoma-root nearly vertical, without projection. Palatal foramina long, reaching backward to the level of the front lamina of $m .^{1}$. Bullæ larger than in $T$. cinereus. Incisors narrow, dark orange in front. Nolar structure much as in $T$. cinereus, $m^{3}{ }^{3}$ distinctly 6-cusped, not 5-cusped as in Peromyscus. 
Dimensions of the type (a female, measured in spirit) :Head and body 96 millim.; tail 130 ; hind foot without claws 24.5 ; ear 18 .

Skull : basal length 23.5 ; basilar length from henselion 22 ; greatest breadth 13.8 ; nasals, length 10 ; interorbital breadth 4.5 ; brain-case, length * $14 \cdot 7$, breadth $12 \cdot 7$; diastema $6 \cdot 7$; palatal foramina $5 \cdot 6$; length of upper molar series $4 \cdot 2$.

Hab. Paramo, south of Chimborazo.

Type: B. M. no. 97. 11. 7.82. Collected by Mr. W. F.H. Rosenberg.

The external proportions and the narrowness and extreme delicacy of the skull will readily separate $T$. paramorum from any of its allies.

\section{Oryzomys vestitus, sp. $\mathrm{n}$.}

Very similar in proportions and general colour above to $O$. meridensis, but the fur very much longer, softer, and woollier. Hairs of the back 14 or 15 millim. in length. General colour grizzled fuscous grey, becoming more rutous posteriorly. Head clearer grey. Ears of medium size, very thinly haired, the few short hairs pale brown. Under surface of body uniformly dirty greyish, the hairs washed with dull buffy terminally; no white on chest or throat ; line of demarcation on sides quite indistinct. Hands and feet dull whitish above. Tail comparatively well-haired, pale brown above and below.

Skull broad and peculiarly depressed in the cranial region, the height of the brain-case being no greater than in an old specimen of $O$. meridensis, while its breadth is very markedly greater. Nasals short and narrow. Interorbital region flattened above, its edges rounded or faintly squared, but not ridged. Anterior edge of zygoma-root quite vertical, without forward projection. Palatine foramina of medium length, but narrow, and unusually far apart, the septum between them 1.5 millim. wide posteriorly; they end in front of $\mathrm{m}^{1}$ a distance equal to the length of $\mathrm{m.}^{3}$. Incisors broad and strong, orange above, yellow below. Molars of normal Oryzomys structure.

Dimensions of the type (an adult male, measured in skin) :-

Head and body 138 millim.; tail 166 ; hind foot 33.3 ; ear 17 .

* The length of the brain-case may be conveniently taken in all Murines from the hinder border of the interparietal to the centre of the line dividing the olfactory chamber from the rest of the brain-case. Internally there is a transverse ridge at this point, which readily shows through on the upper surface. 
Skull : extreme length $36 \cdot 2$; basilar length $29 \cdot 2$; greatest breadth 19.3 ; nasals $12.7 \times 4 \cdot 1$; interorbital breadth 4.9 ; brain-case, length 16.5 , breadth just behind zygoma-root 16 ; interparietal $5 \times 10.6$; palate length from henselion 15.8 ; diastema $10 \cdot 2$; palatal foramina $6.6 \times 3$; length of upper molar series $6 \cdot 2$.

Hab. Rio Milla, Merida, $1630 \mathrm{~m}$. Coll. S. Briceno.

Type: B. M. no. 98. 5. 15. 3. Killed March 7, 1897.

This very peculiar species has a superficial resemblance to O. meridensis, but may be readily distinguished externally by its soft fur and dull-coloured belly. Its broad flat skull is different from that of any species known to me, and even recalls that of the South-African Graphiurus platyops.

\section{Marmosa marica, sp. n.}

Most nearly allied to $M$. pusilla, Desm., but decidedly larger. Fur rather long for this group, the hairs of the back about 10 millim. in length. General colour greyish fawn, not uniform, but decidedly wavy, the darker tips to the hairs so disposed as to give a mottled or wavy appearance to the back. Centre of face paler fawn. Area round eyes black. Cheeks, chin, and throat yellowish or creamy white, the hairs light to their roots; belly similar, but less strongly yellowish, and the hairs slaty basally; line of demarcation on sides not strongly marked. Upper surface of hands and feet dull whitish. Tail very short-haired, paler brown above, rather whiter below.

Skull much larger than in the typical $M$. pusilla. Muzzle broad. Zygomata evenly and boldly expanded. Interorbital space flat, parallel-sided, its edges just thickened into indistinct parallel ridges, not forming postorbital processes. Palate broad. Canines small. Jast upper premolar slightly smaller than the middle one.

Dimensions of the type (an adult male, in skin) :-

Head and body 102 millim.; tail 131 ; hind foot (wet) 16.5 ; ear 16 .

Skull: basal length 25 ; greatest breadth $15^{\cdot} 6$; nasals $12 \times 3 \cdot 6$; interorbital breadth $4 \cdot 8$; palate, length 15 , breadth between outer corners of $m .^{3} 8 \cdot 5$; combined length of $m s .^{1-3} 4 \cdot 7$. Hab. Rio Abbarregas, Merida, Venezuela, alt. $1630 \mathrm{~m}$. Coll. S. Briceno.

Type: B. M. no. 98. 5. 15. 1. Killed Jan. 24, 1897.

This is the species which, with some doubt, I referred to M. pusilla in 1896, but the recent presentation to the Museum of a Paraguayan specimen of that species, practically a topo- 
type, by Mr. J. Graham Kerr, enables me to make a better comparison between the two than was formerly possible. The true pusilla is much smaller, has a narrower and more rounded skull, while its dorsal colour does not show the peculiar waviness which additional material proves to be quite constant in the Merida form. The same is true of Lagoa Santa specimens representing Burmeister's Grymceomys agilis.

\section{Marmosa dryas, sp. n.}

Size of M. marica. Fur long, as in that species. General colour dull rufous fawn, darker and more uniform than in that species. Centre of face but little lighter. Under surface dull rufous throughout, except for a white patch on the chest; no line of demarcation on sides. Cheeks and chin rather paler rufous, not white. Hands and feet whitish above, T'ail very short-haired as usual, brown above, rather paler below.

Skull with a much narrower and more sharply pointed muzzle than in M. marica. Zygomata not so boldly divergent as in that animal, especially anteriorly, where, in fact, their profile, as viewed from above, is almost concave. Interorbital region smooth, its edges diverging backwards, not ridged. Palate longer and narrower than in the allied species, the two rows of teeth more nearly parallel.

Dimensions of the type (an adult skin, said to be that of a male) :-

Head and body 97 millim.; tail 147 ; hind foot (wet) 18.4 ; ear 16.

Skull: basal length $24 \cdot 8$; greatest breadth 15 ; nasals $11.7 \times 3.3$; interorbital breadth 5.2 ; palate, length 15 , breadth between outer corners of $m .^{3} 8 \cdot 1$; combined length of $m s .^{1-3} 4 \cdot 9$.

Hab. Culata, Merida, $4000 \mathrm{~m}$. Coll. S. Briceno.

Type: B. M. no. 98. 5. 15. 2. Killed Dec. 14, 1896.

Some time ago Mr. Briceno sent home a single specimen of this form, but I could not then be sure that it was not a mere spasmodic colour-variation of $M$. marica, but now four additional examples identical with the first have been obtained, and show conclusively that it is really a different species to the common Merida form. It may be readily distinguished by its darker general colour, its dull rutous instead of yellowish-white belly, and its narrower and more pointed skull. 



\section{$2 \mathrm{BHL}$ Biodiversity Heritage Library}

Thomas, Oldfield. 1898. "LXX.—On seven new small mammals from Ecuador and Venezuela." The Annals and magazine of natural history; zoology, botany, and geology 1, 451-457. https://doi.org/10.1080/00222939808678001.

View This Item Online: $\underline{\text { https://www.biodiversitylibrary.org/item/63770 }}$

DOI: https://doi.org/10.1080/00222939808678001

Permalink: https://www.biodiversitylibrary.org/partpdf/60093

\section{Holding Institution}

University of Toronto - Gerstein Science Information Centre

\section{Sponsored by}

University of Toronto

\section{Copyright \& Reuse}

Copyright Status: NOT_IN_COPYRIGHT

This document was created from content at the Biodiversity Heritage Library, the world's largest open access digital library for biodiversity literature and archives. Visit BHL at https://www.biodiversitylibrary.org. 